AJRS

amca2012.org

\title{
Challenges for Pesantren in the Revolution Era of Society 5.0
}

\author{
Yusroful Kholili1,* \\ ${ }^{1}$ University of Muhammadiyah Malang, Indonesia \\ *Corresponding author: Renemada194@gmail.com
}

KEYWORDS

Pesantren

Society 5.0 era

challenges

SUBMITTED 22 Dec 2020

REVISED 15 Jan 2021

ACCEPTED 4 Feb 2021

\begin{abstract}
As the world is entering society 5.0 era, pesantren must be aware of its challenges to maintain its existence as the oldest educational institution. This study aims to determine the challenges faced by Islamic boarding schools in the era of community revolution 5.0. This research is preliminary qualitative research to analyze various literature on Islamic boarding schools' crucial issues in society 5.0 era. The data obtained in the study were collected through documentation techniques which were then tested using source triangulation techniques. The data analysis was through three stages, namely data reduction, data display and conclusion. The results of this study indicate that Islamic boarding schools in the 5.0 era must face contemporary challenges that are in line with the development of science and technology, namely having the ability for morals implanting, technology-based pesantren systems, digital literacy and digital ethics. If this ability can be realized and developed, the pesantren's existence can be maintained and accepted by the community 5.0
\end{abstract}

(c) The Author(s) 2021

\section{INTRODUCTION}

Pesantren is one of the particular institutions of religious education in Indonesia (Abdurrahman, 2018). The educational patterns that characterize pesantren include a hidden curriculum (Halid, 2019), independent leadership patterns that are not co-opted by the state (Wahid, 2002), bandongan and sorogan learning methods, and the study of the yellow book (classical literature) (Sutrisno, 2014).

Apart from being unique and distinctive, pesantren is also considered the oldest religious, educational institutions in Indonesia, which grew along with Islam's entrance in Indonesia (Haris \& Amin, 2020). The first figure who founded the pesantren was Shaykh Maulana Malik Ibrahim in Java (Sunyoto, 2016). He was the first Muslim preacher in Java who came from Gujarat India, who died in 1419 AD.

Along with old pesantren, Nurcholis Madjid considers pesantren to be indigenous institutions (Madjid, 1997), Islamic educational institutions born from society and contain Indonesian authenticity. In line with this assumption, Azra proposed that pesantren emerged and grew from the experiences of society's sociological personalities and then grew, developed, and survived until now (Madjid, 1997).

The assumption that pesantren remains to grow and survive can be proven by pesantren's existence and has increased in number from time to time. According to the latest data released by the Director-General of Islamic Education of the Indonesian Ministry of Religion on July 31, 2019, 27,276 Islamic boarding schools have registered themselves in EMIS with a total of 3,666,467 students. This fact proves that Islamic boarding schools have a significant role in educating the nation's generation in the religious field, which has persisted through Indonesia's long history of education.

In its development, Indonesian education is currently preparing to enter the era of the 5.0 society revolution. Society 5.0 has the concept of big data technology collected by the Internet of things (IoT), which is then transformed by Artificial Intelligence (Skobelev \& Borovik, 2017). into something that can help people live a better life. Like Industry 4.0, Society 5.0 will also affect all aspects of life, including education (Setiawan \& Lenawati, 2020). As part of education, pesantren as one of the Islamic religious education institutions in Indonesia will always be tested along with the times. Several studies related to education and Islamic boarding schools during the development of science and technology, especially in the industrial era 4.0 and society 5.0, have been carried out by several researchers, including Humaidi (2019) who examined the transformation of the salaf Islamic boarding school education model in the industrial era 4.0 in the form of modernization in terms of mastery of foreign languages, entrepreneurship and use of information and communication technology (ICT) $(\mathrm{Hu}-$ maidi, 2019). Mannan (2019) who examines the contextualization of the pesantren curriculum and the Islamic boarding school learning approach in the era of the industrial revolution 4.0 (Manan, 2019); Putra (2019) who examined the challenges of Islamic education in the era of society 5.0 which resulted in the finding that Islamic education in the society 5.0 era must have digitalization skill for the purposes of Islam, Qur'an and Hadith (Putra, 2019); Setiyani, et al. (2020) which examines the principles of education implementation in the disruptive era to welcome society 5.0; However, this study has differences and novelty compared 
to the research, because this study reveals the challenges of Islamic boarding schools in the era of society 5.0 as Islamic educational institutions that must be ready to face the dynamics world changes while maintaining their original identity. Accordingly, this paper aims to determine the challenges faced by Islamic boarding schools in the era of community revolution 5.0 .

\subsection{Pesantren Existence}

Islamic boarding schools are religious institutions that teach, educate, develop and spread Islamic teaching (Abdullah, 2013). Pesantren is an educational institution that aims to instil tauhid, tafaqquh fi ad-din institutions, and human resource development that emphasizes morality in everyday life (Muksin, 2016).

Thus, the pesantren is an Islamic religious teaching institution with authoritative sources by a Kiai to his students (santri), most of whom live in a boarding house/dormitory provided, usually adjacent to the Kiai's residence. Because pesantren activities aim to teach, the method is not essential, so more teaching is done non-classical such as sorogan and bandongan. The essential thing in the spirit of pesantren education is to convey the teachings of Islam so that these teachings are understood and realized as the best way of life to be practised in real life in daily behaviour (Afif, 2019).

Pesantren have specific tools to achieve its purposes, which at the same time distinct pesantren from other educational institutions in Indonesia. These tools are a fundamental component rooted in the pesantren tradition and remain today, namely the boarding school, mosque, santri, teaching of classical Islamic books, and Kiai himself (Rahmatullah \& Said, 2019).

The mosque is a significant element in the pesantren as the central place to educate students. According to the pesantren tradition, the mosque is the most appropriate place for Kiai to teach religious knowledge to students, instil worshiping obligation, and punctuality in performing the five times congregation prayers (Usman, 2013). In this process, the mosque functions as the classical Islamic education tradition, namely as the educational process centre. More importantly, a mosque is a place for the knowledge transfer from Kiai to his students and the center for other activities. Thus, the mosque is a place of worship, learning centre, meeting place, other pesantren activities, and building emotional relationships between students and Kiai(Usman, 2013).

Pondok, the place where santri live, is one of the typical elements of a pesantren that is different from other education systems. With the boarding system, there are at least three functions in the pesantren system (Usman, 2013). First, the dormitory brings students closer to the Kiai, making it easier for them to explore the kiai's knowledge. Second, the pesantren/dormitory, mostly located in rural areas with a small shelter, makes it easier for Kiai to accommodate their students. Third, The boarding system makes students feel an emotional and physical attachment with their Kiai, either as their teacher or even children and fathers.

Kiai is a significant figure for Islamic boarding schools. Generally, Kiai is the founder and owner of the pesantren. Besides, Kiai is an ulama/ religious leader figure who masters the science of religion in-depth and become the primary source for students to explore knowledge in the pe- santren and take role models of daily life in society. Thus, the Kiai becomes the prominent figure in the pesantren tradition, both academically and as a good morals practitioner.

As the pesantren's prominent owner, Kiai holds absolute authority within the pesantren environment (Aini, 2020). Important decisions regarding the leadership and management of pesantren derive from Kiai. Therefore, pesantren is inseparable from the role and experience of the Kiai figure. Likewise, the Kiai is a title referring to a figure in recognition of the wisdom, authority, and charismatic figure of the Kiai (Musaropah, 2018). Therefore, Kiai's guidance and leadership also affect the social community around the pesantren, both locally and national-wide (Aini, 2020).

Santri are students in the pesantren education system. Generally, these students, who are called santri, live with the Kiai. Therefore, Kiai is entitled to an Islamic religious scholar, especially those with in-depth knowledge of classical books, who have students in their residence/pesantren. In the salaf pesantren tradition, there are two kinds of santri (Kushidayati \& Rosyid, 2019), namely: first, santri mukim, namely students who come from distant areas and live in the pesantren. Second, the santri kalong, namely students from villages or areas adjacent to the pesantren buildings, do not live in the pesantren.

Kitab Kuning is a specific element of the pesantren, which differentiates it from other Islamic education. The yellow book is a classic Arabic book written by medieval scholars that becomes the primary material for recitation in Islamic boarding schools. The classical book, which is also called the bald book, taught to non-Arab students, is in Arabic and are without harakat, which becomes a challenge for students to understand the translation and understand its contents. To read and understand the meaning of the yellow book text, a set of Arabic knowledge is needed, such as nahwu, sorrow, the meaning of lafaz in the dictionary and balaghah (Usman, 2013).

Each pesantren has choices regarding the scientific field of Islam, which is a prominent characteristic of expertise. Pesantren researchers then use these characteristics to classify pesantren. The most popular typology of pesantren, among others, according to Dofier, pesantren is divided into three types, namely: Salaf, Khalaf, and Mixed (Afif, 2019).

Salaf (Traditional) Islamic Boarding Schools tend to maintain the conventional education tradition by only teaching works of 15th century Islamic scholars in Arabic (the yellow book) and the non-classical patterns of teaching halaqah, sorogan, and bandongan. The Khalaf Islamic Boarding School is a type of pesantren that teaches Islamic religious knowledge, the national curriculum, and a more significant portion of foreign languages such as Arabic and English by applying the classical system. Mixed Pesantren adopts the last two types of pesantren education systems, namely the traditional and modern systems. The yellow book taught with the sorongan, bandongan, and wetonan methods and implemented learning with a classical system such as madrasah/school are the mixed pesantren characteristics (Afif, 2019).

In its development, research on pesantren continues to grow. This research also adds a theory about pesantren's variation, which is utterly different from the above typology. In other research, Islamic boarding schools are grouped based on superior curricula, namely: mod- 
ern pesantren (highlighting Arabic and foreign language skills), tahassus Islamic boarding schools (tahassus tool science, tahassus fiqh / ushul fiqh science, tafsir/hadith, tasawwuf / thariqat, and qiraat. Alqur'an), and mixed boarding schools (Afif, 2019; Rachman, 2014). Besides, Martin Van Bruinesen successfully created categories for Islamic boarding schools based on their curriculum content, namely simple Islamic boarding schools, moderate Islamic boarding schools, and advanced Islamic boarding schools (Afif, 2019). Some divide the pesantren based on students' types, namely pesantren for children, pesantren for parents, and pesantren (for students in general). With the same perspective, some categorize it into al-Irsyad pesantren, Persis pesantren NU, Muhammadiyah pesantren, and neutral pesantren such as pesantren Gontor and Pesantren al-Yaqin(Afif, 2019).

The divisions of pesantren can continue according to the different perspectives. However, this study's results have not served as a complete picture of pesantren and its education system. This finding indicates that pesantren are always experiencing complex developments and changes. It could be that the previous pesantren, whose curriculum followed the salaf system, has now become modern, or vice versa. It also does not rule out that pesantren only about religious teaching, as now they have madrasas and universities. However, this categorization helps us to understand the varied and always developing forms of pesantren.

\subsection{0 Revolution Era}

Society 5.0 is a concept proposed by Japan on January 21, 2019 (Skobelev \& Borovik, 2017). Indeed, society 5.0 is the antithesis of the 4.0 industrial revolution, eliminating humans' role due to automation, digitalization, and capitalism in the global industrialization project (Aurachman, 2018). The era of society 5.0 serves to help various human needs achieve a better life (Afif, 2019). The difference between industry 4.0, Society 5.0 makes humans the main center of technology in restoring humanist life by utilizing the internet of things (IoT), big data, and artificial intelligence (Holroyd, 2020).

IoT (internet of things) is a technology that allows physical objects connected to the internet network (Nasution, Rizal, Setiawan \& Hasan, 2019). With this technology, objects can connect to the internet and controlled by humans even from a distance. An example of this technology product is the GPS (Global Positioning System) service. Big Data is a breakthrough in database systems. In simple terms, big data is a large amount of data collected at a fast speed (Oliviandi, Osmond, \& Latuconsina, 2018). The use of big data can help humans collect data or information and analyze it quickly and cheaply to make accurate and precise decisions.

$\mathrm{AI}$ is an artificial intelligence created by computers to think like humans. AI can be a machine or software designed and trained to obtain information and regulate the use of information, using rules for the definite conclusion and self-correction (Priyanto, Zarlis, Mawengkang, \& Efendi, 2019). There are two kinds of AI system development: weak AI, which is designed and trained to do specific tasks, and strong AI, which is designed to have cognitive abilities to find a solution without human help (Park \& Park, 2018). The AI system allows a machine embedded with Artificial Intelligence to be smarter when more data is collected (Priyanto, Zarlis, Mawengkang, \& Efendi, 2019).
In society 5.0 , the big data technology collected by AoT has been transformed by AI to help people in their lives (Skobelev \& Borovik, 2017). Concerning the world of education, society 5.0 allows students to learn in front of special machines designed to replace educators or be controlled by educators (Rouf, 2019).

\section{METHOD}

This research uses a qualitative approach, which is according to Moleong, is research conducted to produce descriptive data, both written and spoken about phenomena that are following the research context (Yuliana \& Yanti, 2018). Also, this research is preliminary research that utilizes a variety of library data. The extracted and analyzed data in this study derive from scientific papers in the appropriate context. In this study, data sources are articles, journals, or documents related to pesantren education and the era of society 5.0.

In this research, the data collection method is by documentation technique, examining data from books, scientific writings, and documents related to boarding school education challenges in society 5.0. To test the data validity, researchers used source triangulation techniques to obtain data validity by comparing data obtained from one source with those obtained from other sources.

Data analysis in this study used Miles and Huberman's analysis by carrying out three stages: data reduction, data presentation, and conclusion drawing. Data reduction is by selecting data that is relevant to the research objectives. Data display describes the disclosed data, while conclusion drawing is made after obtaining a complete understanding of the data obtained.

\section{RESULTS AND DISCUSSION}

Pesantren are known as traditional educational institutions in Indonesia that tend to maintain their identities that have been built for a long time (Manan, 2019). On the other hand, times are always evolving, dynamic, and tend to change. Therefore, the existence of pesantren will always face changes and shifts in the value of needs.

According to several studies, pesantren can survive and keep up with these developments despite the time changes. The developments and changes in pesantren, especially salaf pesantren, derive from the initiation of Kiai (Aini, 2020) and the selective-adaptive abilities of pesantren (Afif, 2019). In line with this opinion, Azra said that Islamic boarding schools develop and survive by making accommodations and changes without leaving the basic things they have to face modernization (Solichin, 2015).

Based on this opinion, the development of technology and science does not mean to change the original characteristics of education in the pesantren but facing them accommodatively by remaining consistent with the Islamic boarding school's cultural identity. To prepare accommodative steps, knowing the challenges in society 5.0 era is necessary to maintain the pesantren's original character. These challenges are as follows:

1. Moral and Noble Characteristics Integrated Implanting

In the era of society 5.0, education is encouraged to take advantage of technology, especially to get accurate information quickly (Risdianto, 2019). With this 
technology, the knowledge transfer can be replaced by a machine in which an embedded artificial intelligence system (Risdianto, 2019). With this technology, the process of knowledge transfer can be replaced by machines, but not for the application of soft skills and hard skills. Unless being anticipated, the formation of moral and noble character in the community outside the pesantren will gradually erode. As an educational institution, Pesantren aims at tafaqquh fi addin (transfer and transmission of religious knowledge) and moral emphasis and exemplary. Thus, pesantren's function to form society's social structure that contains high moral values will be increasingly needed. Therefore, the moral values and religious attitudes implanting is not only for students but also for people outside the pesantren.

2. Technology-based System of Pesantren

As noted earlier, society concept 5.0 focuses on the internet of things, big data, and $\mathrm{AI}$ to gather information and transfer knowledge (Putra et al. 2019). If the pesantren can use this technology in the learning process, it will significantly help and comprehensively accelerate comprehension. At least by utilizing this technology in the study of sanad and matan in the science of hadith, asbabun-nuzul, and categorization of verses in the science of tafsir, etc., it will help in learning istidlal (digging arguments) and solving problems based on the rules of jurisprudence (fiqh law) and their solutions quickly. In this context, pesantren are required to have the ability to use and manage technology. With this ability, administrative management and resources in the pesantren, starting from the information and admissions system, teaching and learning activities, to completing the students' learning period, can be recorded neatly in the technology-based management system of the pesantren.

3. Digital Literacy and Ethics

One of the technological development impacts (industrial era 4.0 and society 5.0) is the increase in digital literacy (Ellitan, 2020). This condition allows easy access to information online, including information about religion. Apart from religious education institutions, pesantren also functions as institutions that broadcast religion. Therefore, technology-based preaching and education media are vital. This condition needs to become a concern to balance the Islamic literature spread through social media, especially messages containing intolerant, liberal, and radical conservative ideological biases. Thus, pesantren are also needed to have the ability to produce moderate, humanist, and tolerant Islamic literature based on technology. Additionally, digital literacy also leads to free and uncontrolled penetration of information. This condition encourages the increase in hoaxes, digital crime, digital radicalism, and the lack of clarification and validation of sources, by the least (Yanti \& Yusnaini, 2018). Here the cultivation of digital ethics is significantly necessary. Critical thinking and tabayun is an absolute must to be a concern to be instilled in students. These skills are to maintain the pesantren's intellectual culture, which has an authentic source standard (mu'tabar) and valid scientific transmission (sanad).

\section{CONCLUSION}

Times changes; it is dynamic and prone to change. Therefore, pesantren will always face changes and shifts. The era of society 5.0 affects all aspects of life, including pesantren education.

Therefore, pesantren must know the challenges of the 5.0 era. Based on this research, pesantren's challenges in the 5.0 era are to instil moral values and noble characters, a technology-based boarding school system, digital literacy, and digital ethics. Researchers provide a proposition that this ability is both a challenge and an opportunity for pesantren to maintain their existence. If pesantren can develop this ability, researchers are optimistic that pesantren efforts in the form of transmission and transformation of Islamic teachings and the formation of Islamic morals will still be given and accepted by society 5.0 .

\section{REFERENCES}

Abdurrahman, A. (2018). Implementasi Manajemen Kurikulum Pesantren Berbasis Pendidikan Karakter. ATTURAS J. Stud. Keislam. 4(2).

Halid, A. (2019). Hidden Curriculum Pesantren: Urgensi, Keberadaan dan Capaiannya. Tarbiyatuna J. Pendidik. Islam, 12(2).

Wahid, M. (2002). Menuju Pendidikan Kemandirian: Gagasan Penting dari Pesantren Oleh Rudi Ahmad Suryadi, 544-555.

Sutrisno. (2017). Implementasi Pendidikan Karakter Di Pondok Pesantren Modern Muhammadiyah Boarding School (MBS) Yogyakarta. J. Elektron. Mhs. Pend. Luar Sekol. - S1, 6(5).

Haris, A \& Amin, K. (2020). Model pembelajaran agama Islam berbasis pesantren di Panti Asuhan Al-Ma'wa Sumberpucung Malang," Ta'dibuna J. Pendidik. Islam. 9(1). 117.

Sunyoto, A. (2016). Atlas Wali Songo. Pustaka IIman.

Madjid, N. (1997). Bilik-Bilik Pesantren, Sebuah Potret Perjalanan. Jakarta: Paramadina.

Skobelev \& Borovik. (2017). On The Way From Industry 4.0 to Industry 5.0: From Digital Manufacturing to Digital Society. Int. Sci. J. "Industry 4.0, 2(6).

Setiawan, D. \& Lenawati, M. (2020). Peran dan Strategi Perguruan Tinggi dalam Menghadapi Era Society 5.0. Res. Comput. Inf. Syst. Technol. Manag., 3(1).

Humaidi, A. (2019). Bargaining Pesantren di Era Revolusi Industri 4.0, Pros. Nas., vol. 2.

Manan, M.A. (2019). Daya Tahan dan Eksistensi Pesantren Di Era 4.0, J. Pendidik. Islam Indones., 3(2).

Putra, P.H. (2019). Tantangan Pendidikan Islam dalam Menghadapi Society 5.0. Islam. J. Ilmu-Ilmu Keislam., 19(2), 99-110.

Setiyani, S., Dasilah, \& Nurcahyo, D.N. (2020). Paradigma Baru Pendidikan Era Disruptif Menuju Masyarakat 5.0," in Prosiding seminar nasional pendidikan program pascasarjana Universitas PGRI Palembang 10 Januari 2020.

Abdullah, Z. (2013). Peranan Pondok Pesantren Dalam Menyiapkan Generasi Muda Di Era Globalisasi. Jurnal Ummul Qura 3(2).

Muksin, M. (2016). Mencetak Sarjana Muslim Kaffah Lewat Pendidikan Pesantren Kampus," Al-Ibrah, 1(2).

Afif, M. (2019). Penerapan Metode Sorogan dalam Meningkatkan Baca Kitab di Pondok Pesantren Tarbiyatun Nasyi'in, KABILAH J. Soc. Community, 4(2), 34-43. 
Rahmatullah, R. \& Said, A. (2019). Implementasi Pendidikan Karakter Islam di Era Milenial pada Pondok Pesantren Mahasiswa. J. TA'LIMUNA, vol. 8, no. 2.

Usman, M.I. (2013). Pesantren Sebagai Lembaga Pendidikan Islam (Sejarah Lahir, Sistem Pendidikan, Dan Perkembangannya Masa Kini). J. al-Hikmah, 14(1).

Aini, M.Q. (2020). Peran Kepemimpinan Kyai dalam Manajemen Strategi Pendidikan Pesantren. Leadership Jurnal Mhs. Manaj. Pendidik. Islam, 1(1).

Musaropah, U. (2018). Kharisma Kyai Dalam Organisasi Pendidikan Pesantren Tradisional. Ulumuddin J. Ilmu-ilmu Keislaman, 8(8).

Kushidayati, L. \& Rosyid, M. (2019). Preserving Pegon: A Case Study on Kampung Santri Tarjumah in Tambangsari, Pati Regency-Central Java, Al Qalam, 36(2).

Rachman, A. A. (2014). The Impact of Authoritarian Leadership System, Reli. J. Stud. Agama-agama, 4(2).

Aurachman, R. (2018). Perancangan Influence Diagram Perhitungan Dampak Dari Revolusi Industri 4.0 Terhadap Pengangguran Kerja, J. Teknol. DAN Manaj. Ind, 4(2).

Holroyd, C. (2020). Technological innovation and building a 'super-smart' society: Japan's vision of society 5.0, J. Asian Public Policy.

Nasution, M., Rizal, M., Setiawan, D., \& Hasan, M.A. (2019). IoT Dalam Agrobisnis Studi Kasus: Tanaman Selada Dalam Green House, IT J. Res. Dev, 4(2).

Oliviandi, S. Osmond, A.B. \& Latuconsina, R. (2018). Implementasi Apache Spark Pada Big Data Berbasis Hadoop Distributed File System, e-Proceeding Eng., 5(1).
Priyanto, D., Zarlis, M., Mawengkang, H. \& Efendi, S. (2019). Studi Literatur Konsep Dasar Machine Learning Dan Neural Network," Semin. Nas. Mat. dan Terap., vol. 1.

Park, W. J. dan Park, J. B. (2018). History and application of artificial neural networks in dentistry, European Journal of Dentistry, 12,(4).

Rouf, A. (2019). Reaktualisasi dan Kontekstualisasi Kearifan Lokal dengan Manhaj Global: Upaya menjawab problematika dan tantangan pendidikan di era Society 5.0 dan Revolusi Industri 4.0 in Seminar Nasional Pascasarjana 2019.

Yuliana, Y.M.S. \& Yanti, R.P. (2018). Efektivitas Program Partisipatif Kelompok Perempuan dalam Meningkatkan Swadaya Masyarakat," J. Surya Masy., 1(1).

Solichin, M.M. (2015). Kebertahanan Pesantren Tradisional Menghadapi Modernisasi Pendidikan," Karsa J. Soc. Islam. Cult., 22(1).

E. Risdianto, Analisis Pendidikan Indonesia di Era Revolusi Industri 4.0, Reseach Gate, no. April, 2019.

Putra, B.S., Rohman, A., Diantoro, K., Soderi, A., \& Puteri, W.R. (2019). Implementasi SPMI Sebagai Upaya Perguruan Tinggi Menghadapi Era 5.0, in Prosiding Seminar Nasional Sistem Penjaminan Mutu Internal Perguruan Tinggi.

Ellitan, L. (2020). Competing in the Era of Industrial Revolution 4.0 and Society 5.0 Background, J. Maksipreneur. 10(1).

Yanti, M. \& Yusnaini, Y. (2018). The Narration of Digital Literacy Movement in Indonesia," Informasi, 48(2). 